\title{
STUDY OF CUSTOMER DEMAND FOR CLOTH MASKS DURING THE COVID-19 PANDEMIC AND AN AFFECTING THE PERFORMANCE: INSIGHT THE INDUSTRIAL ORGANIZATION THEORY IN MANAGEMENT RESEARCH
}

\author{
Krismantoro $^{1}$ and Wilhelmus Hary Susilo ${ }^{2 *}$ \\ Magister of Management, Faculty of Economics and Business, University of Persada Indonesia YAI \\ DOI: http://dx.doi.org/10.38193/IJRCMS.2021.3501
}

\begin{abstract}
The Covid-19 pandemic caused by the SARS-CoV-2 virus caused the World Health Organization (WHO) to issue rules, one of which is the obligation to use masks for all people in public places. The study found that people who always wear masks during high exposures have a 70 percent lower risk of infection compared to those who don't wear masks, and evidence in other studies found that when wearing masks was strictly applied on long-haul flights, infected passengers did not transmit the virus to others on board. The Industrial Organization theory would conduct to explore; product, distribution, sales, price and performance. The research was drive within the quantitative and descriptive analytic design management research and the result was indicating that it must be easy to seller and be aware to deliver within the markets place.
\end{abstract}

KEYWORDS: Consumer demand, Performance, Market place, Research model

\section{INTRODUCTION}

The use of this mask as a form of prevention of Covid-19 transmission through droplets. Droplets are fluids that come out of the respiratory tract. Transmission through droplets is avoided because the SARS-CoV-2 virus is widely encountered in the human respiratory tract. Initially, the Government based on advice from WHO urged healthy people not to use masks. Before this appeal existed, there was a scarcity of masks and the price of existing masks was very high up to 10 times. Covid-19 continues to spread and cause thousands of deaths around the world, leading who to issue rules for the use of masks for everyone, both healthy and sick people. The increasing demand for masks and the scarcity of existing masks make the government allow people to use cloth masks.

Moreover, the masks are devices designed to protect users from inhaling airborne particles and protect the health of the respiratory tract. Masks are also commonly used by working groups, when safety techniques and tools are unfit or ineffective to reduce dust levels, masks become the last and very simple defense solution to use, masks themselves become an efficient method of protecting workers, with more than three million workers required to wear masks to protect themselves from occupational hazards. Masks also in the community have been clearly shown to reduce influenza infections 
compared to not wearing masks (Macintyre et al, 2013).

Nevertheless, no official research on the effectiveness of the use of cloth masks for the prevention of Covid-19 transmission. WHO requires the use of cloth masks made of three layers. The first layer is recommended to use materials that can absorb droplets. The second layer can be a tissue insert or likened to the material in the first layer. The third layer, or the outermost layer made of hydrophobic is a type of material that is able to prevent the entry of droplets. This 3-layer cloth mask effectively holds about 70 percent of droplet particles. In Indonesia, many one-layer cloth masks are made from scuba. This mask is not recommended to wear because it is only able to withstand 0-5 percent of incoming particles, aka not effective at all. Keep in mind, cloth masks should be replaced immediately when dirty, wet, or have been worn for more than 4 hours. However, the use of cloth masks can prevent the entry and exit of droplets even though it is not $100 \%$. The use of medical masks that are more effective in preventing transmission of the virus is recommended for use by medical personnel and people who are sick.

There are many different types of masks, one of which is the P100 mask. P100 masks are significantly more protective than those of N95 masks, where P100 filter masks produce better performance against particles measuring 10 - $400 \mathrm{~nm}$ compared to N95 filter masks. The selection of masks to be used by health workers is based on the assessment of risk factors / exposure, the spread of possible infections, the unexpected spread of the disease, the severity of the disease in patients being served, and the availability of masks in health services (MacIntyre \&Chughtai, 2015).

The consumer demand according to (Chen et al., 2014), that the sales and business platform would be aware to deliver the product within the normal price. The holistic customer demand could determine the sales team initiative, re-solving the contradictive, the critical chain management as a research gap. (Sana, 2013, Newton et al., 2014, Santos and D'Antone, 2014)

Furthermore, the study would explore the antecedent's factor to pursue firm's performance within market base research such as, product development, price, production, and sales to the market within the global pandemic.

\section{LITERTATURE REVIEW}

\section{Mask1. Definition of Mask}

A mask is a respiratory protection used as a method to protect an individual from inhaling harmful substances or contaminants that are in the air, respiratory protection or a mask is not intended to replace the preferred method that can eliminate disease, but is used to adequately protect the wearer (Cohen \&Birdner, 2012). Masks are widely used to provide protection against particles and aerosols that can cause harm to the respiratory system faced by people who do not wear personal protective 
equipment, the dangers of particles and aerosols of different sizes and chemical properties can harm humans, hence NIOSH recommends masks that use filters (Eshbaugh et al, 2009).

Masks themselves have many types, one of which is Air Purifying Respirators (APR), this mask uses filters or catridges that can prevent harmful substances that are in the air (Harper, 2012). Masks have the type that can be protected depending on the level of danger from exposure to aerosols or harmful particles that are in the air. According to Cohen \& Birdner (2012) the type of mask has the following types:

1. Quarter mask be a The respirator Include Hiding and mouth with cover face elongated from above nose until below mouth mask this the bias Used to protection towards danger particle that low.

2. half mask is a half-mask respirator that covers the nose and mouth with a face covering that extends from the top of the nose down the chin, this mask is used for all types of hazards, including particles, vapors and gases that can harm its use.

3. full facepiece is a respirator with a full face covering that covers the entire head, this mask is usually used on particles, aerosols and gases that can irritate the eyes.

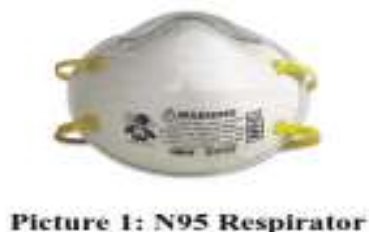

Picture 1: N95 Respirator

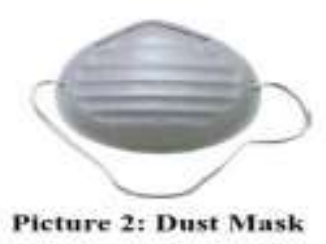

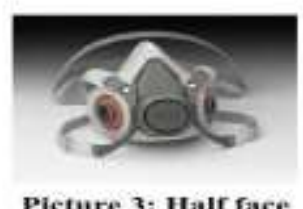

Picture 3: Halr face

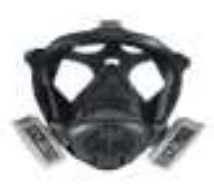

Pieture 4: Full Face

(Environmental Health \& Safety,2015)

\section{Mask Function}

Filtration masks have several functions and filters that are used to protect against exposure to the dangers of gases, particles and aerosols. The types of masks used according to $3 \mathrm{M}$ Occupational Health and Environmental Safety Division (2010) are:

1. N-series filter

$\mathrm{N}$-series type masks have a limitedness used for oil-free aerosols, this mask can be used for solid and liquid particulates that can harm the respiratory system. This mask has two types, namely N95 masks where the mask can filter particles about $95 \%$ with $0.3 \mu \mathrm{m} \mathrm{Nacl}$ aerosol, while N100 mask at least apat filter $99.97 \%$ measuring $0.3 \mu \mathrm{m} \mathrm{Nacl}$ aerosol.

2. R-series filter

$\mathrm{R}$-series masks are be filtered masks to reduce any harmful particles based on oil aerosols that can 
harm the body and this mask is only used for 8 hours. This mask has a type that is R95 where the mask can filter $95 \%$ of oil aerosols measuring $0.3 \mu \mathrm{m}$ DOP (Dioctyl Phthalate) aerosols.

\section{P-series filter}

A P-series filter is a filtered mask to reduce any particles including oil-based liquids or aerosols. This mask has type P95 which can filter 95\% of oil aerosols measuring $0.3 \mu \mathrm{m}$ DOP (Dioctyl Phthalate) aerosols, while this type $\mathrm{P} 100$ has a catridge that can filter $99.97 \%$ of oil aerosols measuring $0.3 \mu \mathrm{m}$ DOP (Dioctyl Phthalate) aerosols.

P100 mask is a mask that has a filter or cartridge that serves to filter any particles including particles or liquids based on oil aerosols, NIOSH requires that this type P-series mask is not used more than 40 hours or use for 30 days. (Occupational Health \& Environmental Safety Division, 2010). Further, the N95 masks (equivalent to FFP/P2 in European countries) are electrostatic ally made microfiber polypropylene designed for filter particles measuring $100-300 \mathrm{~nm}$ in diameter with $95 \%$ efficacy. Measurement of single particles Covid-19 approximately 125 nm (Elsayed, 2020; Feng, 2020).

Some studies have found no clinically significant evidence of a protective difference between surgical masks and N95 (Elsayed, 2020; Smith, 2016; Long, 2020). Even aerosol droplets $(<5 \mu \mathrm{m})$ can be blocked with a surgical mask. The study by (Leung, 2020) in which out of 10 subjects without masks tested obtained 4 subjects contained corona virus particles in their breath. While the other 10 subjects who used masks reported none of them contained the corona virus in their breath. On the other hand (Bae, 2020) reported that of the four Covid-19 positive subjects who did not use surgical masks or cloth masks effectively filtered corona virus particles during coughing, even more virus contamination was found outside the surface of the mask than the inner surface.

\section{Universal masking}

The most important benefit of continuous use of masks is to provide protection and prevent the spread of the virus from asymptomatic, mild symptomatic and pre-carrier symptoms (Leung, 2020). Studies estimate that viral load rates in patients who are asymptomatic and symptomatic during the natural course of the disease have something in common, making it with a high potential to transmit (Zou, 2020) in addition, many studies report transmission that occurs from asymptomatic patients from various clusters including: families (Pan, 2020) and people who are unknowingly carriers of the virus in various locations (Bai, 2020; Wei, 2020) even inside the health care center (Kimball, 2020).

The use of masks is the most likely policy because we cannot predict who and where the virus can be transmitted. The rejection comes as studies report that of the 20-50\% of reported cases of transmission; only $1-2 \%$ of transmission in the general public is caused by asymptomatic cases (Rhee, 2020). This makes the universal masking policy must be accompanied by other policies such as body temperature 
checking and screening of Covid-19 symptoms. Universal masking is also reported to improve the psychological well-being of health workers, decrease anxiety about exposure to disease (Tirupathi, 2020), and can give the impression of false protection if the use and selection of masks is not appropriate.

\section{Masks for kids, should they?}

Protecting healthy children with masks can be very difficult, many opinions recommend that children under the age of 2 years do not wear any type of mask because they have very small airways, they have potential difficulty breathing (Esposito, 2020). Especially for infants, all that can be done is to maintain physical distance, along with washing hands and avoiding licking objects, to reduce the risk of SARS-CoV-2 infection as highlighted by the American Academy of Pediatrics.

The surgical masks are starting to be suitable for children from 3 to 12 years of age. Toddlers and first-year school children, masks often don't fit and don't fit on the face at risk of being contaminated with air (Esposito, 2020). Children don't like to wear masks and will most likely try them to remove or even throw them away, so they touch their face more. Preparing and teaching healthy children to wear masks is needed to get maximum compliance. The selection of masks in children should take precedence when going out of the house or going to school. But if possible other efforts can be made, namely staying at home, maintaining distance, washing your hands often, and using a face shield.

Table 1. The benefits and disadvantages of different types of masks in virus protection

\begin{tabular}{|c|c|c|c|}
\hline Type of Mask & Feature & Benefits of protection & Deficiency \\
\hline $\begin{array}{l}\text { Powered Air- } \\
\text { Purifying } \\
\text { Respirators } \\
\text { (PAPRs) }\end{array}$ & $\begin{array}{l}\text { - Headgear can be adjusted } \\
\text { - Equipped with batteries } \\
\text { - Equipped with a powered } \\
\text { blower to filter the air. } \\
\text { For use during aerosol } \\
\text { generation (AGP) procedures. }\end{array}$ & $\begin{array}{l}\text { - Greater protection } \\
\text { compared to N95.- No } \\
\text { conformity test on face } \\
\text { shape and size. } \\
\text { - More comfortable. - Not } \\
\text { disposable. Not making. } \\
\text { tightness because the air } \\
\text { flow is smooth. }\end{array}$ & $\begin{array}{l}\text {-Expensive, limited availability. } \\
\text { - High costs and difficult } \\
\text { maintenance. }\end{array}$ \\
\hline N95 Respirator & $\begin{array}{l}\text { - The design fits tight. } \\
\text { (Filtration rate>95\%) } \\
\text { - Used by health workers. }\end{array}$ & $\begin{array}{l}\text { Greater protection } \\
\text { against aerosols and } \\
\text { droplets from medical } \\
\text { masks. }\end{array}$ & $\begin{array}{l}\text { - Requires a test } \\
\text { regular suitability and checking } \\
\text { of mask seals. } \\
\text { - Limited supplies. - It's more } \\
\text { expensive than a medical mask. }\end{array}$ \\
\hline Surgical mask & $\begin{array}{l}\text {-Loose form. - Main } \\
\text { designation for health workers } \\
\text { People with symptoms of } \\
\text { Covid-19. } \\
\text { - People who treat patients } \\
\text { who are confirmed and } \\
\text { suspected of Covid-19. }\end{array}$ & $\begin{array}{l}\text { - Cheaper, easier to come } \\
\text { by. } \\
\text { - Protection above } 90 \% \text {. }\end{array}$ & $\begin{array}{l}\text { - There's still a possible air leak. } \\
\text { - Disposable. }\end{array}$ \\
\hline
\end{tabular}




\begin{tabular}{|c|c|c|c|}
\hline & $\begin{array}{l}\text { People aged } 60 \text { years and } \\
\text { above and at high risk. }\end{array}$ & & \\
\hline Cloth mask & $\begin{array}{l}\text { Loose installation, usually } \\
\text { made from polyester or } \\
\text { cotton. } \\
\text { Can be coated with filter } \\
\text { paper (highly recommended } \\
\text { in pandemic times). } \\
\text { - For use by the general } \\
\text { public. }\end{array}$ & $\begin{array}{l}\text { - Self-made, washed and } \\
\text { reused. } \\
\text { - Use can prevent the } \\
\text { stockpiling of medical } \\
\text { mask waste. }\end{array}$ & $\begin{array}{l}\text { Does not provide adequate } \\
\text { protection from } \\
\text { aerosols. }\end{array}$ \\
\hline
\end{tabular}

Source: (WHO, 2020; Tirupathi, 2020)

\section{The Theoretical Support}

The Industrial Organizational theory would to rooted within the economic dynamics and always focus to drive focused on business strategic, aware to the market- structure and the most important to attempt the firm's performance. (Hult, 2011)

Further, the industrial organization always aware to the strategic mass-production within the masks, determine the emergence market- place within the same industries, the structure and its interactions, attempt the well collaborated among division in firms and to achieve the performance for long run business and anticipated the demand dynamics. (Miao and Evans, 2013, Gelper et al., 2016, Zimmerhackel et al., 2018, Koo et al., 2017)

The customer heterogeneity demand and demand un-certainty could anticipate within the focus- firms strategic with the consumer orientation and support from the upper echelons'.(Dilek et al., 2016, Adner and Levinthal, 2001, Nguyen, 2012, Formica and Uysal, 2016)

\section{RESEARCH MODEL AND METHODS}

The inquiry was building the research- model base on the previous research and theoretical rooting of the Industrial theory and the quantitative method would conduct the descriptive analytic research design in management science, such as, figure 1, below (Dilek et al., 2016, Hult, 2011, Schultz and Block, 2015, Barger et al., 2016, Lütjen et al., 2017): 


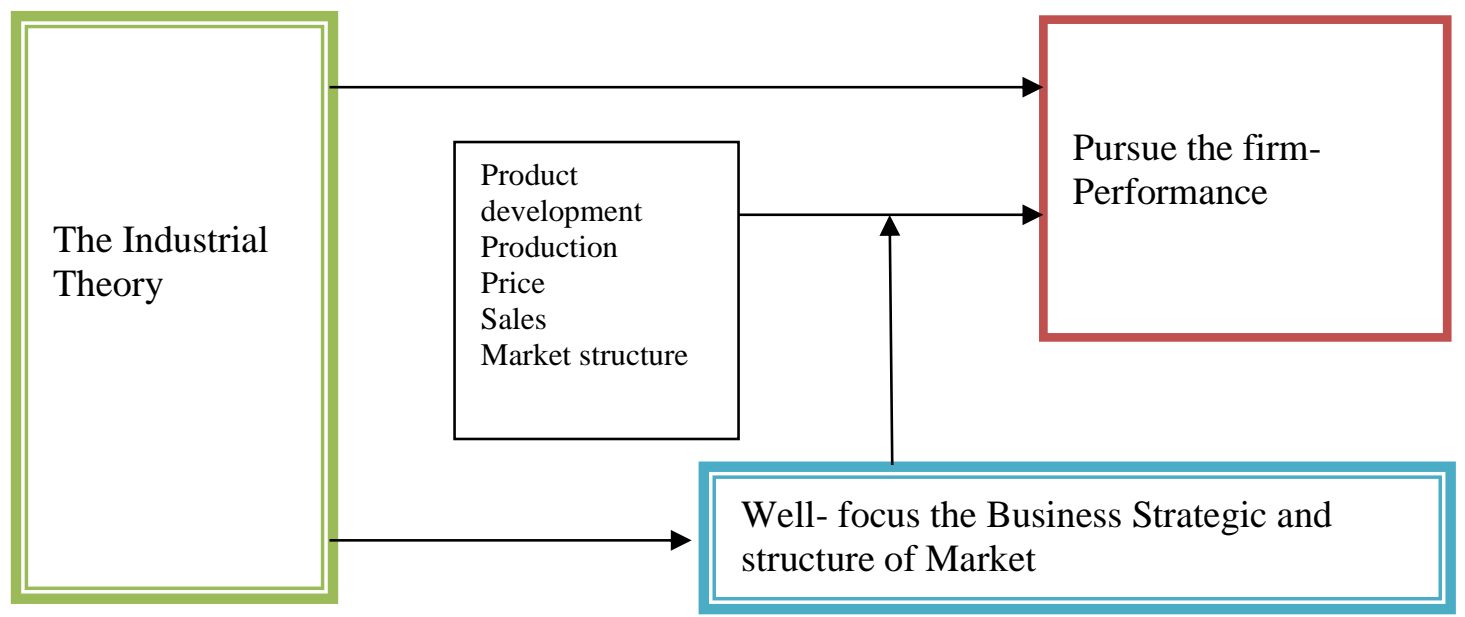

Figure 1. The Research Model to Pursue the Firm Performance

\section{RESULT AND DISCUSSION}

The Masks are one of the Personal Protective Equipment (APD) used to protect the mouth, nose, and face from airborne pathogens, droplets, and splashes of infected body fluids (Trossman, 2016). The mask consists of a cloth mask, a surgical mask, and an N95 respirator (MacIntyre \&Chughtai, 2015).The N95 mask is part of a filtering piece air-purifier respirator. This type of mask is a product that can filter PM with a size of 0.3 by $95 \%$. In terms of price and technical use, N95 masks have advantages over other types of air purifier masks in the face of air pollution. N95 masks are different from procedure masks whose filtration capabilities are not certified by NIOSH.

The COVID-19 N95 mask recommended by cdc as safe or preferred personal protective equipment for patients with positive COVID-19. The function of this mask is as follows:

1. Placement on tight face (tight fit)

2. Masks are designed to be incurable with the mouth (e.g. bowl or duckbill shape) and have a nondamageable shape.

3. Ability to ltrasi better than surgical mask

4. Recommended in direct treatment of patients with Covid-19

5. With this mask the user can breathe well while wearing it (In eventual Pressure/ $\Delta \mathrm{P}<5.0 \mathrm{mmH} 2 \mathrm{O}$ $1 \mathrm{~cm} 2)$

6. Pass the Bacteria Filtration E in vitro (BFE), Particle Filtration - Breathing Resistance, Splash Resistance, and Flammability tests

7. Decrease exposure to airborne contamination. 
Moreover, the related to the use of masks this causes the use of masks to increase in Indonesia. One of the most requested masks is the N95 mask. This mask is called effective to anticipate the spread of the corona virus in Indonesia because it has the ability to filter 95 percent of the air and as a filter of harmful particles, respiratory protective equipment is a tool used to cover the mouth and nose with materials that can filter the entry of dust or steam (Harrianto in Purwanti: 2014). Masks to protect dust or particles that enter the respiratory tract, can be made of cloth of a certain size (A.M. Sugend Budiono in Miftasari: 2012). The mask filters particles when air is inhaled through the mechanism of capturing and depositing particles by filter-forming fibres (Moeljosoedarmo in Purwanti: 2014). Purwanti (2014) mentioned that the use of masks can prevent the possibility of respiratory system disorders due to exposure to air with high dust levels. The demand for masks in markets in Indonesia is increasing so that distributors almost run out of mask stock as a result of which the price of masks soared. The high price of masks makes consumers who need masks complain about the increase in masks even some find the price of masks rose 10 times the price of ordinary masks.

Solomon (2011:61) argues that consumer behavior learns about everything about how processes occur when consumers choose, buy, use or discard a product, idea, or experience to satisfy the needs and desires of the consumer itself. Here are the results of interviews that have been conducted to 30 community respondents who have purchased masks during the Covid-19 pandemic. The results are shown in table 2 as follows:

Table2. Preliminary Research Results

\begin{tabular}{|l|l|l|l|}
\hline No. & Indicators & Agree & Disagree \\
\hline A. & Price & 8 & 22 \\
\hline $\mathbf{1}$ & The price of the mask is in accordance with the quality of protection. & 10 & 20 \\
\hline $\mathbf{2}$ & Cut-price masks with government assistance & 22 & 8 \\
\hline $\mathbf{3}$ & Surgical masks and N95s are still expensive. & & \\
\hline $\mathbf{B}$ & Distribution & 19 & 11 \\
\hline $\mathbf{1}$ & The seller's ability to meet the need -consumers & 23 & 7 \\
\hline $\mathbf{2}$ & Health Masks that are hard to come by & 25 & 5 \\
\hline $\mathbf{3}$ & Fabric masks make it easy for sellers to re-market & 5 \\
\hline
\end{tabular}

Furthermore, based on preliminary research from the price factor, it is seen that there are $26 \%$ of the public who still choose masks according to their quality and protection, 33\% discounted masks with government assistance, $73 \%$ agree to surgical masks and N95 is still expensive. Then from the distribution factor, $63 \%$ of sellers' ability to meet consumer needs, $76 \%$ of health masks and N95 are hard to come by, and $83 \%$ of cloth masks make it easier for sellers to be re-marketed.

From the data has shown that people still choose masks that are in accordance with quality and in 
terms of excellent protection and also health masks and N95 is still very expensive when the Covid19 pandemic so that the community is very difficult to get, then it is a cloth mask that makes it easier for consumers and sellers in getting it Pharmaceutical industry players state that the production of masks in Indonesia is no longer able to meet the increasingly bloated demand. President Director of PT Bio Farma (Persero) as well as the holding company of BUMN Pharmaceutical it was because of the Corona virus that made people panic and demand rose while supply did not increase. According to Honesti, the company does not have mask production. However, Kimia Farma as a holding member who has an N95 mask has now made sure it does not have an adequate supply. "Yesterday was asked for one million N95 masks, frankly it cannot be fulfilled because all existing N95 masks will be given to BNPB in accordance with government instructions to be distributed to medical workers and at the location of guarding in and out of citizens that the company currently continues to cooperate with research institutions and related stakeholders such as the Ministry of Health in the search for corona virus seeds. However, it is very difficult at this time to directly concoct drugs and vaccines to prevent the corona virus. In China, no cure has been found yet. Not to mention, the manufacture of a vaccine takes at least 15 years. "So our campaign is for the public to further increase their endurance either with vaccines that are already like flu vaccines or routine consumption.

PT Kimia Farma Tbk. had distributed 16 million medical masks and 1 million non-medical masks as of April 18, 2019. President Director of Kimia Farma. The party will continue to increase the distribution of masks through cooperation with the Ministry of Cooperatives and Small and Medium Enterprises (Kemenkop-UKM). He stated that until now it does not have a mask production facility. Thus, cooperation with medical and non-medical mask manufacturers is needed to meet the increasing needs of masks in the midst of the coronavirus pandemic. "About 2 weeks ago, we cooperated with the Ministry of SME so that it could be an off-taker production of non-medical SMEs, which of course already meets the requirements of the Ministry of Health and BNPB, so in early May it is expected to increase the number of mask supplies," he explained in the RDP with Commission VI of the House of Representatives, Tuesday (04/21/2020). He stated that it also continues to ensure the number of masks is available throughout kimia farma's network of pharmacy outlets. The Company also limits the number of purchases to 2 pieces per person. President Director of PT Bio Farma (Persero) - the holding parent of state-owned Pharmaceuticals - state-owned pharmaceutical companies would not take advantage during this pandemic.

Moreover, the prices of masks and drugs needed for the handling of the coronavirus did not increase even though the price of raw materials had soared. Kimia Farma (KAEF) Targets 2020 Revenue to Rise 24 Percent to Rp11.7 Trillion "The mask, which still maintains the price of the mask is only Kimia Farma, at the end of March we are still selling Rp2,000 per sheet. This is to maintain enough supply, but because we only expect a supply area, there because of high demand, many starts to raise prices," added that during a situation like this, pharmaceutical SOEs will move as agents of 
development. In other words, it will rule out the position of the red plate company as a value creator. Hence, the number of drug and medical device mafias today is caused by the many transactions that are still bridged by third parties. Therefore, he emphasized that state-owned pharmaceutical companies will only transact directly with the main principle of medical devices or related drugs. PT Kimia Farma (Persero) restricts the purchase of masks for everyone, where only two sheets of masks are allowed for each transaction at outlets or pharmacies owned by Kimia Farma. This was conveyed by Minister of State-Owned Enterprises (SOE), where Kimia Farma has 1,300 outlets throughout Indonesia. "Two sheets per day at a price of Rp2,000 per sheet. If his brother or neighbor or who buys another mask, go ahead. We cannot limit the people, what is limited is the number of purchases. Further, the Kimia Farma will not raise the current price of mask sales during the coronavirus outbreak. "Sorry, I mean in times of difficulty, Kimia Farma does not raise prices. That is its function, SOEs are present for the people in accordance with the president's vision," he added. Therefore, the people do not need to panic because masks, hand sanitizers, vitamins that increase endurance are available at Kimia- Farma pharmacies.

\section{CONCLUSION AND SUGGESTION}

1. Masks can be used either to protect a healthy person (worn to protect themselves when in contact with an infected person) or to control the source (worn by an infected person to prevent further transmission).

2. Masks are tools used to protect breathing apparatus such as the nose and mouth from the risk of dangers such as smoke, dust and the smell of mild chemicals. Masks are usually made of cloth. This respiratory mask serves to protect the respiratory organs by filtering the contamination of chemicals, micro-organisms, dust particles, aerosols, vapors, smoke, or gases. So that the air inhaled into the body is clean and healthy air. This mask consists of various types, such as respirators, canisters, diving tanks and regulators, and respiratory aids. Finally, the Indonesian nation must be able to make raw materials for the manufacture of masks, to maintain the continuity of mask production to meet the needs of masks in the country and also to maintain the stability of the price of masks.

\section{Acknowledgement}

Thank you so much to the Expertise and Experience Learning Club, Faculty of Business and Management, University of Persada Indonesia Y.A.I. To my colleague and students. To in Kind Workshops The NEW- E\&EL CLUB LABORATORY FEB UPI Y.A.I team.

Declaration of conflicting interests

The scholar declared no potential conflicts of interest with respect to the investigated, authorship, publication within this manuscript.

Funding

The authors did not receive the financial support for this research and publication of this manuscript.

ORCID:000-0002-6758-1159, URL: orcid.org/0000-0002. And SCOPUS ID: 56539508300. 


\section{BIBLIOGRAPHY*}

Dewi, N.A., and Sri, U.2020.Design of Cloth Masks as Personal Protective Equipment in Sustainable Fashion System.Jurnal Da Moda 1(2):32-41.

WHO Interim Guide: Recommendations on The Use of Masks in the Context of Covid-19 The Central Management of the Indonesian Pediatricians Association.2020.FAQ on The Use of Masks. [Online] covid19.idionline.org. [accessed] July 29, 2020.Redaksi.2020.Get to know the Types of Masks to Prevent Covid-19. [Online] Jurnalse- curity.com. [accessed] July 29, 2020.

Infection prevention and control during health care when COVID-19 is suspected: interim guidance. Geneva: World Health Organization; 2020

"Kimia Farma Boss: We Make Sure the Mask Price Is Rp 2,000/pcs!", March 4, 2020, cnbcindonesia.com/market/20200304162956-17-142512/ boss-kimia-farma-we-make sureprice-mask-rp-2000-pcs, accessed March 5, 2020.

Kimia Farma: Price Does Not Rise, Cloth Mask in Kimia Farma Rp. 2,000 per Sheet,

News, BUMN Product Info, BUMN Newspaper. Com, March 4, 2020

Limit Buyers, Kimia Farma Says Mask Stock Is Still 4,000 dus,

Monica Wareza, CNBC Indonesia, March 4, 2020

MacIntyre, C. R., Seale, H., Dung, T.C., Hien, N. T., Nga, P. T., Chughtai, A. A., ... Wang, Q. (2015). A cluster randomised trial of cloth masks compared with medical masks in healthcare workers. BMJ Open, 5(4), e006577. http://doi.org/10.1136/lomjopen-2014-006577

MacIntyre, C.R., \& Chughtai, A.A. (2015). Facemasks for the prevention of infection in healthcare and community settings. BMJ (Clinical Research Ed.), 350, h694. http://doi.org/10.1136/bmj.h694

Trossman, S. (2016). Respirator or procedure mask? Resource available to help nurses, patients stay $\begin{array}{lllll}\text { safe. } & \text { Retrieved } & \text { May } & \text { 2016, } & \text { from }\end{array}$ http://www.theamericannurse.org/index.php/2016/03/16/respirator-orprocedure-mask/

Aninda Istika Miftasari2012 Relationship Between Dust Levels and The Use of Masks with Vital Lung Capacity

Ika Purwanti

2014 Relationship of the use of Masks to Forced Vital Capacity and volume of First Second Forced Respiration in Palm Oil Processing Workers PT. Nusantara XIII Rimba Plantation

Michael R. Solomon. (2011), "Consumer Behaviour. Buying, Having, and Being", Pearson Education, Inc.

Cohen DE, Jacob SE. Allergic Contact Dermatitis (2012). In: Wolf K, Goldsmith LA,Katz SI, Gilchrestba, Paller US, Leffel DA,ed. Flitzpatricks Dermatology in General Medicine 7th General Medicine: The McGraw-Hill Companies, Inc.

Eshbaugh, J. et al., 2009. N95 and p100 Respirator Filter Efficiency Under High Constant and Cyclic 
Flow, J Occup Environ Hyg, 6. doi: 10.1080/15459620802558196.

Mayes, Peter A., Bender, David A. 2012. Harper Biochemist 29. Egc Medical Book Publisher: Jakarta. Abd-Elsayed A, Karri J. Utility of Substandard Face Mask Options for Health Care Workers During the COVID-19 Pandemic. Anesth Analg. 2020. doi: 10.1213/ ANE.0000000000004841.

Bae S, Kim M, Kim JY, et al. Effectiveness of Surgical and Cotton Masks in Blocking SARS-CoV-

2: A Controlled Comparison in 4 Patients. Ann Intern Med.2020. doi: 10.7326/M20-1342.

Bai, Y. et al.(2020) 'Presumed Asymptomatic Carrier Transmission of COVID- 19', JAMA - Journal of the American Medical Association.doi: 10.1001/jama.2020.2565.

Esposito, S. and Principi, N. (2020) 'To mask or not to mask children to overcome COVID-19', European Journal of Pediatrics. European Journal of Pediatrics, 179(8), pp. 1267-1270. doi: 10.1007/s00431-020-03674-9.

Feng, S. et al.(2020) 'Rational use of face masks in the COVID-19 pandemic', The Lancet Respiratory Medicine,8(5), pp. 434-436. doi: 10.1016/S2213- 2600(20)30134-X.

Kimball, A. et al.(2020) 'Asymptomatic and Presymptomatic SARS-CoV-2 Infections in Residents of a Long-Term Care Skilled Nursing Facility — King County, Washington, March 2020', MMWR. Morbidity and Mortality Weekly Report. doi: 10.15585/mmwr.mm6913e1.

Leung, C.C., Lam, T. H. and Cheng, K. K. (2020) 'Mass masking in the COVID- 19 epidemic: people need guidance', The Lancet. doi: 10.1016/S0140- 6736(20)30520-1.

Leung, N. H. L. et al.(2020) 'Respiratory virus shedding in exhaled breath and efficacy of face masks', Nature Medicine.doi: 10.1038/s41591-020-0843-2.

Rhee, C., Baker, M. and Klompas, M. (2020) 'The Covid-19 Infection Control Arms Race', Infection Control and Hospital Epidemiology.doi: 10.1017/ice.2020.211.

Tirupathi, R. et al.(2020) 'Comprehensive Review of mask utility and challenges during the COVID19 pandemic', Infezioni in Medicina, 28, pp. 57-63.

Wei, W. E. et al.(2020) 'Presymptomatic Transmission of SARS-CoV-2- Singapore', Morbidity and Mortality Weekly Report.

World Health Organization (2020) 'Advice on the use of masks in the context of COVID-19', Who, (April), pp. 1-5. Available at: https://www.who.int/publications-.

World Health Organization (2020) 'WHO updated guidance on the use of masks', (30).

Zou, L. et al.(2020) 'SARS-CoV-2 viral load in upper respiratory specimens of infected patients', New England Journal of Medicine.doi: 10.1056/NEJMc2001737.

\section{REFERENCE**}

ADNER, R. \& LEVINTHAL, D. 2001. Demand heterogeneity and technology evolution: implications for product and process innovation. Management science, 47, 611-628. 
BARGER, V., PELTIER, J. W. \& SCHULTZ, D. E. 2016. Social media and consumer engagement: a review and research agenda. Journal of Research in Interactive Marketing, 10, 268-287.

CHEN, J., CHEN, J., GOH, K.-Y., XU, Y. \& TAN, B. C. Y. 2014. When do sellers bifurcate from Electronic Multisided Platforms? The effects of customer demand, competitive intensity, and service differentiation. Information \& Management, 51, 972-983.

DILEK, S., KESGINGÖZ, H. \& IŞIK, S. 2016. An Analysis of Halva Price and Demand Dynamics by Granger Causality. Procedia - Social and Behavioral Sciences, 235, 522-529.

FORMICA, S. \& UYSAL, M. 2016. Destination Attractiveness Based on Supply and Demand Evaluations: An Analytical Framework. Journal of Travel Research, 44, 418-430.

GELPER, S., WILMS, I. \& CROUX, C. 2016. Identifying Demand Effects in a Large Network of Product Categories. Journal of Retailing, 92, 25-39.

HULT, G. T. M. 2011. Toward a theory of the boundary-spanning marketing organization and insights from 31 organization theories. Journal of the Academy of Marketing Science, 39, 509-536.

KOO, T. T. R., LIM, C. \& DOBRUSZKES, F. 2017. Causality in direct air services and tourism demand. Annals of Tourism Research, 67, 67-77.

LÜTJEN, H., TIETZE, F. \& SCHULTZ, C. 2017. Service transitions of product-centric firms: An explorative study of service transition stages and barriers in Germany's energy market. International Journal of Production Economics, 192, 106-119.

MIAO, C. F. \& EVANS, K. R. 2013. The interactive effects of sales control systems on salesperson performance: a job demands-resources perspective. Journal of the Academic Marketing Science, 41, 73-90.

NEWTON, J. D., EWING, M. T. \& COLLIER, P. M. 2014. Resolving contradictions in institutional demands through loose coupling. Industrial Marketing Management, 43, 747-753.

NGUYEN, D. X. 2012. Demand uncertainty: Exporting delays and exporting failures. Journal of International Economics, 86, 336-344.

SANA, S. S. 2013. Sales team's initiatives and stock sensitive demand - A production control policy. Economic Modelling, 31, 783-788.

SANTOS, J. B. \& D'ANTONE, S. 2014. Reinventing the wheel? A critical view of demand-chain management. Industrial Marketing Management, 43, 1012-1025.

SCHULTZ, D. E. \& BLOCK, M. P. 2015. U.S. online shopping: Facts, fiction, hopes and dreams. Journal of Retailing and Consumer Services, 23, 99-106.

ZIMMERHACKEL, J. S., ROGERS, A. A., MEEKAN, M. G., ALI, K., PANNELL, D. J. \& KRAGT, M. E. 2018. How shark conservation in the Maldives affects demand for dive tourism. Tourism Management, 69, 263-271. 